\title{
ABSTRAK \\ "Pengaruh Metode Pembelajaran Praktikum Simulasi Terhadap Pencapaian Kompetensi Klinik Mahasiswa Semester VI (lima) S1 Keperawatan di STIKes Bina Generasi Polewali Mandar"
}

\author{
Nur Isriani Najamuddin ${ }^{1}$, Ahid Jahidin ${ }^{2}$ Sri Mustika Surya ${ }^{3}$, Fira Fatmasari ${ }^{4}$
}

(xii+57 halaman+ 7tabel+ 1lampiran+9Kepustakaan+8jurnal)

Latar Belakang:Sistem pendidikan nasional menekankan bahwa pendidikan adalah usaha sadar dan terencana untuk mewujudkan suasana belajar dan proses pembelajaran agar peserta didik secara aktif mengembangkan potensi diri, kepribadian, kecerdasan, akhlak mulia serta ketrampilan yang diperlukan dirinya, masyarakat, bangsa dan negara. Peraturan pemerintah Nomor 19 Tahun 2005 tentang standar nasional pendidikan disebutkan bahwa Rumah Sakit sebagai wahana kegiatan belajar klinik keperawatan yang bermutu dan mampu bersaing di tingkat nasional, regional dan internasional dalam pengetahuan, keterampilan, kemandirian dan sikap untuk menemukan, mengembangkan serta menerapkan ilmu, teknologi dan seni yang bermanfaat bagi kemanusiaan (Anonimous, 2009)..

Tujuan: Untuk mengetahui metodepembelajaranpraktikumsimulasi terhadap pencapaian kompetensi klinik mahasiswa semester VI (lima) S1 keperawatan di STIKes Bina Generasi Polewali Mandar.

Desain penelitian:Penelitian ini dilaksanakan mulai tanggal 29 Januari 2018 sampai 05 Februari2018. Pengambilan sampel dengan cara TotalSampling dan banyaknya anggota sampel adalah 16 orang. Responden yang dijadikan sampel dalam penelitian ini adalah mahasiswa S1 Keperawatan STIKes Bina Generasi Kabupaten Polewali Mandar yang akan melakukan praktik klinik di rumah sakit

Hasil penelitian: Hasil analisis data dengan menggunakan dengan menggunakan Uji $t$ berpasangandiperoleh Penilaian Sikap menunjukkan nilai $p=0,000<\alpha 0,05$ sedangkan hasil uji untuk Penilaian Pengambilan Spesimen Darah menunjukkan nilai $p=0,000<\alpha 0,05$. Maka ini berarti Ha diterima Ho di tolak, maka ada pengaruh metode pembelajaran praktikum simulasi terhadap pencapaian kompetensi klinik mahasiswa semester V (lima) S1 keperawatan di STIKes Bina Generasi Polewali Mandar.

Kesimpulan:Berdasarkanhasilpenelitianinimenunjukanbahwaada pengaruh yang signifikan antara pre test dan post test metode pembelajaran praktikum simulasi terhadap pencapaian kompetensi klinik mahasiswa semester V (lima) S1 keperawatan di STIKes Bina Generasi Polewali Mandar. 
Kata Kunci:metodepembelajaran, simulasi,kompetensiklinik.

\title{
ABSTRACT \\ "The Influence of Simulation Practicum Learning Methods on Achieving Sixth (Five) Semester Students' Clinical Competence on Nursing at PolewaliMandar Generation Development Stikes"
}

\author{
Nur Isriani Najamuddin ${ }^{1}$, Ahid Jahidin ${ }^{2,}$ Sri Mustika Surya ${ }^{3}$, Fira Fatmasari ${ }^{4}$ \\ $($ xii +57 pages +7 tables +1 attachment +9 library +8 journals $)$
}

Background: The national education system emphasizes that education is a conscious and planned effort to realize the learning atmosphere and learning process so that students actively develop their own potential, personality, intelligence, noble character and skills needed by themselves, society, nation and country. Government Regulation Number 19 of 2005 concerning National Education Standards states that the Hospital is a vehicle for learning quality nursing clinics that are capable of competing at national, regional and international levels in the knowledge, skills, independence and attitude to find, develop and apply science, technology and art that is beneficial to humanity (Anonimous, 2009)

Objective: To find out the learning method of simulation practicum towards the achievement of clinical competence of the sixth (five) semester students of nursing S1 at PolewaliMandarBinaGenerasiSTIKes.

Research design: This research was conducted from January 29, 2018 to February 5, 2018. Sampling was done by means of Total Sampling and the number of sample members was 16 people. Respondents who were sampled in this study were S1 Nursing STIKes students of PolewaliMandar Regency who would conduct clinical practice in hospitals

The results of the study: The results of data analysis using paired t test obtained Attitude Assessment showed $p$ value $=0,000<\alpha 0,05$ while the test results for Assessment of Blood Specimen Retrieval showed $p=0,000<\alpha 0,05$. Then this means that $\mathrm{Ha}$ is accepted by $\mathrm{Ho}$ and rejected, then there is the effect of simulation practicum learning method on the achievement of clinical competence in the fifth semester (five) undergraduate nursing students at PolewaliMandarBinaGenerasiSTIKes.

Conclusion: Based on the results of this study indicate that there is a significant influence between pre-test and post-test simulation method of learning practicum 
on the achievement of clinical competence of fifth semester (five) undergraduate nursing students at PolewaliMandarBinaGenerasiSTIKes.

Keywords: learning method, simulation, clinical competence

\section{PENDAHULUAN}

\section{LatarBelakang}

Sistem pendidikan nasional menekankan bahwa pendidikan adalah usaha sadar dan terencana untuk mewujudkan suasana belajar dan proses pembelajaran agar peserta didik secara aktif mengembangkan potensi diri, kepribadian, kecerdasan, akhlak mulia serta ketrampilan yang diperlukan dirinya, masyarakat, bangsa dan negara. Peraturan pemerintah Nomor 19 Tahun 2005 tentang standar nasional pendidikan disebutkan bahwa Rumah Sakit sebagai wahana kegiatan belajar klinik keperawatan yang bermutu dan mampu bersaing di tingkat nasional, regional dan internasional dalam pengetahuan, keterampilan, kemandirian dan sikap untuk menemukan, mengembangkan serta menerapkan ilmu, teknologi dan seni yang bermanfaat bagi kemanusiaan (Anonimous, 2009).

$\begin{array}{lr}\text { Pendidikan memiliki peran } \\ \text { penting dalam mempersiapkan } \\ \text { sumber daya manusia yang } \\ \text { berkualitas.Pendidikan } & \text { yang } \\ \text { berkualitas adalah pendidikan yang } \\ \text { bermutu.Mutu pendidikan suatu } \\ \text { bangsa dapat dikatakan berkualitas } \\ \text { apabila pendidikan rang } \\ \text { dilaksanakan dapat memberikan }\end{array}$

lulusannya

kemampuan, pengetahuan, dan keterampilan.(Sukmadinata, 2009).Salah satu indikator keberhasilan pendidikan, ditunjukan dengan pencapaian prestasi belajar.Dengan prestasi belajar yang baik seseorang dapat menyelesaikan pendidikan tepat pada waktunya, melanjutkan pendidikan kejenjang yang lebih tinggi, mudah untuk mendapatkan pekerjaan sebagai kebutuhan sehingga mampu mempertahankan hidupnya. Selain itu prestasi belajar sebagai bentuk aktualisasi diri, dan pengakuan terhadap keberadaannya sehingga memberi manfaat kepada orang lain, bangsa dan negara, memberi kepuasan batin pada diri sendiri dan motivasi untuk berprestasi dan menghasilkan Sumber Daya Manusia (SDM) yang berkualitas. (Amrkimi, 2011)Salah satu faktor yang mempengaruhi prestasi belajar adalah gaya belajar. Gaya belajar/ Pola belajar merupakan cara yang cenderung dipilih seseorang untuk menerima dan memproses informasi dari lingkungan.Gaya belajar harus diperhatikan agar materi pelajaran dapat lebih mudah dimengerti dan potensibelajar dapat berkembang lebih optimal.(Susilo, 2009).

Pendidikan tenaga kesehatan di selenggarakan untuk 
menghasilkan tenaga kesehatan dalam jumlah dan jenis serta mutu yang disesuaikan dengan tuntunan masyarakat. Dalam era kesejagatan dewasa ini dituntut adanya sumber daya manusia yang mampu bekeija secara profesional dalam segala bidang termasuk upaya pelayanan kesehatan. Peranan tenaga kesehatan sangat menentukan keberhasilan pelaksanaan program pembangunan di bidang kesehatan untuk mencapai visi Indonesia sehat 2010. Salah satu strategi mencapai Indonesia sehat 2010 adalah peningkatan kualitas sumber daya tenaga kesehatan melalui pendidikan tenaga kesehatan yang profesional.Pendidikan tenaga kesehatan profesional tersebut di awali dan proses pendidikan yang baik dimana peserta didik tidak hanya mendapat pendidikan di kelas dalam bentuk kuliah, seminar dan diskusi, tetapi juga proses pembelajaran klinik yang dilakukan di laboratorium dan dilahan praktek.

Pendidikan dalam arti luas adalah suatu proses untuk mengembangkan semuaaspek keperibadian manusia ke arah yang lebih baik, yang mencakup pengetahuaan,nilai dan sikap, serta keterampilannya (Serudji, 2008).Keberhasilan pendidikan dalam arti sempit ditentukan oleh sejauh manapenguasaan peserta didik terhadap kompetensi yang meliputi pengetahuan, nilai dansikap, serta keterampilan. Sedangkan dalam arti luas, keberhasilan pendidikan, ditentukan oleh sejauh mana kompetensi yang dimiliki itu dapat diterapkan ataudirasakan manfaatnya oleh masyarakat (Serudji, 2008). Hal ini juga berlaku padapendidikan keperawatan. Keberhasilan pendidikan keperawatan tercermin dariserangkaian kompetensi profesional yang dikuasai oleh lulusan yang dihasilkannyayang selanjutnya disebut perawat profesional.

Penelitian ini menilai sikap mahasiswa dan cara pengambilan specimen darah. Menlai sikap mahasiswa agar mahasiswa dapat mengembangkan perilaku jujur, disiplin, tanggung jawab, peduli, santun, dan menunjukan sikap sebagaian dari solusi atas berbagai permasalahan dalam berinteraksi secara efektif dengan lingkungan social dan alam serta dapat menempatkan diri sebagai cerminan yang baik.Menilai penilaian pengambilan specimen darah pada mahasiswa untuk mengetahui teknik pengambilan darah vena yang baik dan memenuhi syarat untuk dilakukan pemeriksaan.

Pembekalan/Pendidikan

klinik merupakan hal yang sangat penting dalam sebuah pendidikan keperawatan, karena pembekalan klinik merupakan proses belajar mahasiswa untuk mencapai kompetensi klinik.

Berdasarkan uraian diatas, penulis tertarik untuk melakukan penelitian dengan judul 
"Bagaimanakah pengaruh metode pembelajaran praktikum simulasi terhadap pencapaian kompetensi

\section{METODOLOGI PENELITIAN}

\section{Desain Penelitian}

Agar penelitian dapat berjalan sebagaimana mestinya, rancangan penelitian harus disusun dan ditentukan sebelum melakukan penelitian. Rancangan penelitian secara umum mencakup dari identifikasi masalah hingga tekhnik analisis data yang akan dilakukan. Secara khusus sering menyebut desain penelitian dengan makna jenis penelitian yang akan digunakan untuk mencapai tujuan penelitian. Desain penelitian yang dipilih akan membawa konsekuensi pada aturan desain tersebut. Oleh karena itu, pemilihan desain penelitian harus disesuaikan dengan tujuan yang ingin dicapai. Pemilihan desain penelitian yang tepat akan menentukan bobot penelitian yang akan dilakukan. Pemilihan desain harus disesuaikan dengan topic penelitian dengan memilih yang paling efisien dan dengan hasil yang memuaskan.(Saryono, 2011)

Penelitian dengan metode survei, peneliti survei adalah jenis penelitian yang bertujuan untuk mengumpulkan informasi yang berhubungan dengan prevalensi, distribusi dan hubungan antar klinik mahasiswa semester V (lima) S1 keperawatan di STIKes Bina Generasi Polewali Mandar?"

variabel penelitian. Pengumpulan data pada penelitian ini biasanya dilakukan dengan cara menyebar kuesioner, wawancara ataupun observasi. Penelitian survei ini mengandalkan informasi yang diperoleh dari responden yang umumnya menggunakan kuesioner dalam memperoleh data.Penelitian ini dilakukan dengan menganalisis pengaruh metode pembelajaran praktikum simulasi terhadap pencapaian kompetensi klinik mahasiswa.

\section{Populasi dan Sampel}

\section{Populasi}

Populasi dalam penelitian ini adalah mahasiswa keperawatan semester V (Lima) di STIKes Bina Generasi Polewali Mandar berjumlah 17 orang.

\section{Sampel}

Sebagian dari populasi yang mewakili populasi disebut sebagai sampel agar hasil penelitian sesuai dengan tujuan, maka penentuan sampel yang dikehendaki harus sesuai dengan kriteria tertentu yang ditetapkan.Kriteria ini berupa kriteria inklusi (batasan ciri/karakter umum pada subyek penelitian, dikurangi karakter yang termasuk kriteria 
ekslusi) dan kriteria ekslusi (sebagian subyek yang memenuhi kriteria inklusi harus dikeluarkan dari penelitian karena berbagai sebab yang dapat mempengaruhi hasil penelitian sehingga terjadi bias.(Machfoedz, 2017) Jadi, Besarnya sampel dalam penelitian ini berjumlah16 orang

\section{HASIL PENELITIAN DAN PEMBAHASAN}

\section{Hasil Penelitian}

\section{Analisis Univariat}

Berikut ini penelitian akan menyajikan analisa data univariat terhadap setiap variabel dengan menghasilkan distribusi frekuensi dan persentasi serta analisa bivariat untuk megetahui hubungan dari inependen dan variabel dependen dengan menggunakan Uji $t$ berpasangan.

Data primer diambil melalui tehnik wawancara tidak terstruktur dan observasi langsung yang dilakukan pada responden.

\section{Distribusi Responden}

Distribusi responden berdasarkan umur:

Tabel 4.1

Distribusi Responden Berdasarkan Karakteristik Umur Mahasiswa S1 Keperawatan STIKES Bina

Generasi Polewali Mandar

\begin{tabular}{|c|c|c|c|}
\hline NO & $\mathrm{U}$ & $\mathrm{N}$ & $\mathrm{P}(\%)$ \\
\hline 1. & 20 & 1 & 6.25 \\
\hline 2. & 21 & 10 & 62.5 \\
\hline 3. & $>22$ & 5 & 31.25 \\
\hline \multicolumn{2}{|c|}{ Jumlah } & 16 & 100 \\
\hline
\end{tabular}

Sumber : Data Primer 2018

Berdasarkan umur didapatkan bahwa umur paling banyak adalah 20 tahun yaitu 10 responden

$(62.5 \%)$ kemudian $<22$ tahun yaitu 5 responden $(31,25 \%)$ dan umur 20 tahun sebanyak 1 responden $(6.25 \%)$.

Distribusi responden berdasarkan berdasarkan jenis kelamin :

Tabel 4.2

Distribusi Responden Berdasarkan Karakteristik Jenis 


\section{Kelamin Mahasiswa S1 Keperawatan STIKES \\ Bina Generasi Polewali Mandar}

\begin{tabular}{|c|c|c|c|}
\hline No & JK & N & P (\%) \\
\hline 1. & Laki - Laki & 5 & 31.25 \\
\hline 2. & Perempuan & 11 & 68.75 \\
\hline \multicolumn{2}{|c|}{ Jumlah } & 16 & 100 \\
\hline
\end{tabular}

Sumber : Data Primer 2018

Berdasarkan

Jenis Kelamin dari 16

respoden mempunyai

jumlah yang paling

banyak adalah perempuan sebanyak

11 responden

(68.75\%) dan laki-laki sebanyak 5 responden

$(31.25 \%)$.

Distribusi Frekuensi Metode Pembelajaran Simulasi Pre-Test Penilaian Sikap Mahasiswa Semester V (Lima) S1 Keperawatan Di STIKes Bina Generasi Polewali Mandar

Tabel 4.3

Distribusi Frekuensi Metode Pembelajaran Simulasi Pre-Test Penilaian Sikap

\begin{tabular}{|c|l|c|c|}
\hline \multicolumn{4}{|c|}{ Pre- Test Penilaian Sikap } \\
\hline No & Penilaian Sikap & Frekuensi & Persent (\%) \\
\hline 1. & Lulus & 7 & 43.75 \\
\hline 2. & TidakLulus & 9 & 56.25 \\
\hline & Jumlah & 16 & 100.0 \\
\hline
\end{tabular}

Sumber : Data Primer 2018

Berdasarkan

tabel 4.3 diatas

didapatkan dari 16

responden yang lulus

pada test penilaian

sikap sebanyak 7 responden atau $(43.75 \%)$ dan yang tidak lulus test penilaian sikap sebanyak 9 responden atau $(56,25 \%)$.

Distribusi Frekuensi Metode Pembelajaran Simulasi Pre-Test Penilaian Pengambilan Spesimen Darah Mahasiswa Semester V (Lima) S1 Keperawatan Di STIKes Bina Generasi Polewali Mandar 
Distribusi Frekuensi Metode Pembelajaran Simulasi PreTest Penilaian Pengambilan Spesimen Darah

\begin{tabular}{|c|c|c|c|}
\hline \multicolumn{4}{|c|}{ Pre- Test Penilaian Pengambilan Spesimen Darah } \\
\hline No & $\begin{array}{c}\text { Penilaian Pengambilan } \\
\text { Spesimen Darah }\end{array}$ & $\mathrm{F}$ & $\mathrm{P}(\%)$ \\
\hline 1. & Lulus & 4 & 25.00 \\
\hline 2. & TidakLulus & 12 & 75.00 \\
\hline & Jumlah & 16 & 100.0 \\
\hline
\end{tabular}

Sumber : Data Primer 2018

Berdasarkan

tabel 4.4 diatas

didapatkan dari 16

responden yang lulus

pada test penilaian

pengambilan

spesimen darah sebanyak 4 responden atau $(25.00 \%)$ dan yang tidak lulus test penilaian sikap sebanyak $\quad 12$ responden atau $(75,00 \%)$.

Distribusi Frekuensi Metode Pembelajaran Simulasi Post-Test Penilaian Sikap Mahasiswa Semester V (Lima) S1 Keperawatan Di STIKes Bina Generasi Polewali Mandar

Tabel 4.5

Distribusi Frekuensi Metode Pembelajaran Simulasi Post-Test Penilaian Sikap

\begin{tabular}{|l|l|c|c|}
\hline \multicolumn{4}{|c|}{ Post- Test Penilaian Sikap } \\
\hline No & \multicolumn{1}{|c|}{ Penilaian Sikap } & $\mathrm{F}$ & $\mathrm{P}(\%)$ \\
\hline 1. & Lulus & 16 & 100.00 \\
\hline 2. & TidakLulus & 0 & 0.0 \\
\hline & Jumlah & 16 & 100.0 \\
\hline
\end{tabular}

Sumber : Data Primer 2018

Berdasarkan

tabel 4.5 diatas

didapatkan dari 16

responden yang lulus

pada test penilaian

sikap sebanyak 16 responden atau $(100,0 \%)$ dan yang tidak lulus test penilaian sikap sebanyak 0 responden atau $(0,0 \%)$.

Distribusi Frekuensi Metode Pembelajaran Simulasi Post-Test Penilaian Pengambilan Spesimen Darah Mahasiswa Semester V (Lima) S1 Keperawatan Di STIKes Bina Generasi Polewali Mandar 
Tabel 4.6

Distribusi Frekuensi Metode Pembelajaran Simulasi PostTest Penilaian Pengambilan Spesimen Darah

\begin{tabular}{|c|c|c|c|}
\hline \multicolumn{4}{|c|}{ Pre- Test Penilaian Pengambilan Spesimen Darah } \\
\hline No & $\begin{array}{c}\text { Penilaian Pengambilan } \\
\text { Spesimen Darah }\end{array}$ & F & P (\%) \\
\hline 1. & Lulus & 16 & 100.00 \\
\hline 2. & TidakLulus & 0 & 0.0 \\
\hline & Jumlah & 16 & 100.0 \\
\hline
\end{tabular}

Sumber : Data Primer 2018

Berdasarkan tabel responden atau $(100,0 \%)$

4.6 diatas didapatkan dari dan yang tidak lulus test 16 responden yang lulus penilaian pengambilan pada test penilaian specimen darah sebanyak pengambilan spesimen darah sebanyak 16

\section{Analisis Bivariat}

Analisa bivariat dilakukan untuk melihat ada pengaruh metode pembelajaran praktikum simulasi terhadap pencapaian kompetensi klinik mahasiswa semester V (lima) S1 keperawatan di STIKes Bina Generasi Polewali Mandar.

Tabel 4.7

Pengaruh Metode Pembelajaran Praktikum SimulasiTerhadap Pencapaian Kompetensi Klinik Mahasiswa Semester V (Lima) S1 Keperawatan di STIKes Bina Generasi Polewali Mandar.

\begin{tabular}{|l|c|c|c|}
\hline & N & Mean & P-Value \\
\hline Pre - Post Penilaian Sikap & 16 & -1.688 & 0.000 \\
\hline $\begin{array}{l}\text { Pre - Post Penilaian } \\
\begin{array}{l}\text { Pengambilan Spesimen } \\
\text { Darah }\end{array}\end{array}$ & 16 & -12.875 & 0.000 \\
\hline
\end{tabular}

Sumber : Data Primer 2018

Berdasarkan analisis
di atas, Hasil uji t
berpasangan untuk Penilaian
Sikap menunjukkan nilai $p=$
$0,000<\alpha 0,05$ sedangkan hasil uji untuk Penilaian Pengambilan Spesimen Darah menunjukkan nilai $p=0,000$ 
$<\alpha$ 0,05. Maka ini berarti Ha

diterima Ho di tolak, maka

ada pengaruh metode

pembelajaran praktikum

simulasi terhadap pencapaian kompetensi klinik mahasiswa semester V (lima) S1 keperawatan di STIKes Bina Generasi Polewali Mandar.

\section{Pembahasan}

\section{Praktikum Simulasi Penilaian Sikap Sebelum dan Sesudah}

Berdasarkan tabel 4.3 diatas didapatkan dari 16 responden yang lulus pada test penilaian sikap sebanyak 7 responden atau $(43.75 \%)$ dan yang tidak lulus test penilaian sikap sebanyak 9 responden atau $(56,25 \%)$.

Dan hasil dari post-test menunjukan bahwa dari 16 responden yang lulus pada test penilaian sikap sebanyak 16 responden atau $(100,0 \%)$ dan yang tidak lulus test penilaian sikap sebanyak 0 responden atau $(0,0 \%)$.

Hal ini menunjukan bahwa sikap mahasiswa mengalami peningkatan sesudah test simulasi dilakukan dan terdapat perbedaan nilai sikap mahasiswa yang bisa dilihat dari nilai yang tidak lulus dan nilai yang tidak lulus sebelum dan sesudah pendidikan kesehatan. Penilaian sikap dengan kategori tidak lulus sebelum test simulasi menunjukkan bahwa mahasiswa masih sedikit yang mempunyai pemahaman yang mendalam tentang sikap terhadap pasien. Penilaian sikap dengan kategori tidak lulus dapat disebabkan karena mahasiswa belum pernah mendapatkan informasi yang benar tentang bagaiman sikap yang baik didepan pasien atau saat pembelajaran sedang berlangsung mahasiswa tidak memahami dengan baik pembelajaran yang sedang diberikan atau ada hal yang mengganggu mahasiswa saat pendidikan berlangsung. Tetapi setelah dilakukan test simuasi pengetahuan dengan kategori tidak lulus menjadi $0 \quad(0.0 \%)$ dari 9 $(56,25 \%)$. Secara teori disebutkan bahwa semakin banyak seseorang mendapatkan informasi mengenai suatu pembelajaran maka pengetahuannya pun akan meningkat. Akan tetapi bila sumber informasi tidak tepat, maka tidak menjamin terbentuknya pengetahuan yang baik.(Notoatmodjo, 2010).

Hal ini sesuai teori yang menjelaskan bahwa sikap seseorang ditentukan oleh semakin banyak objek yang diketahui maka akan menimbulkan sikap makin positif terhadap objek tertentu, dimana sikap terdiri dari beberapa tingkatan yaitu menerima, merespon, menghargai dan bertanggung jawab atas apa yang telah diketahui sehingga mampu bersikap yang lebih positif. Sikap merupakan respon yang muncul sebelum tindakan. Proses awalnya 
adalah seseorang menyadari dan mengetahui stimulus yang diberikan, kemudian sikap subjek mulai timbul terhadap stimulus kepada pasien, sampai pada akhirnya terbentuk suatu sikap positif untuk mencoba melakukan sesuai dengan stimulus. (Notoatmodjo, 2007)

Tujuan metode simulasi yaitu membantu peserta didik mempraktikan keterampilan dalam membuat keputusan dan penyelesaian masalah, mengembangkan kemampuan interaksi antarmanusia dan memberikan kesempatan peserta didik untuk menerapkan berbagai prinsip, teori, serta untuk meningkatkan kemampuan kognitif, afektif, dan psikomotor.

Kelebihan metode simulasi, Memperkaya pengetahuan, sikap dan keterampilan, serta pengalaman yang tidak langsung diperlukan dalam menghadapi berbagai masalah sosial., Peserta didik berkesempatan untuk menyalurkan perasaan yang terpendam sehingga mendapat kepuasan, kesegaran, dan kesehatan jiwa., Sekalipun bukan tujuan model ini, melalui simulasi dapat dikembangkan bakat dan kemampuan yang mungkin dimiliki oleh peserta didik, misalnya dalam seni drama, bermain peran, dan sebagainya.

\begin{tabular}{ccr}
\multicolumn{2}{c}{ Kekurangan } & metode \\
Simulasi, & Pengalaman & yang
\end{tabular}

diperoleh melalui simulasi tidak selalu tepat dan sempurna dengan kenyataan dilapangan atau dalam kehidupan.Tidak jarang simulasi dijadikan sebagai alat hiburan, sedangkan fungsinya sebagai alat belajar jadi terabaikan.Pelaksanaan simulasi sering menjadi kaku, bahkan jadi salah arah, karena kurangnya pengalaman keterampilan atau penguasaan siswa terhadap masalah sosial yang diperankan.Simulasi dipengaruhi oleh faktor-faktor emosional seperti rasa malu, ragu-ragu, atau takut yang dapat memengaruhi peserta didik dalam melakukan simulasi.Simulasi menuntut hubungan informal antara guru dan peserta didik yang akrab dan fleksibel serta ruang dan fasilitas yang selalu tersedia dengan baik.

Penelitian ini menilai sikap mahasiswa dan cara pengambilan specimen darah. Menlai sikap mahasiswa agar mahasiswa dapat mengembangkan perilaku jujur, disiplin, tanggung jawab, peduli, santun, dan menunjukan sikap sebagaian dari solusi atas berbagai permasalahan dalam berinteraksi secara efektif dengan lingkungan social dan alam serta dapat menempatkan diri sebagai cerminan yang baik.

\section{Praktikum Simulasi Penilaian Pengambilan Spesimen Darah Sebelum dan Sesudah \\ Penelitian ini menunjukan bahwa saat pre-test penilaian}


pengambilan specimen darah didapatkan dari 16 responden yang lulus pada test penilaian pengambilan spesimen darah sebanyak 4 responden atau $(25.00 \%)$ dan yang tidak lulus test penilaian sikap sebanyak 12 responden atau $(75,00 \%)$.

Dan data post-test didapatkan dari 16 responden yang lulus pada test penilaian pengambilan spesimen darah sebanyak 16 responden atau $(100,0 \%)$ dan yang tidak lulus test penilaian pengambilan specimen darah sebanyak 0 responden atau $(0,0 \%)$.

$\begin{array}{rlr}\text { Dari } & \text { hasil penilaian } \\ \text { pengambilan } & \text { specimen } & \text { darah }\end{array}$ menunjukan bahwa pengetahuan mahasiswa mengalami peningkatan sesudah test simulasi dilakukan dan terdapat perbedaan nilai pengetahuan mahasiswa yang bisa dilihat dari nilai yang lulus dan nilai yang tidak lulus sebelum dan sesudah test simulasi. Penilaian pengambilan specimen darah dengan kategori tidak lulus sebelum test simulasi menunjukkan bahwa mahasiswa masih sedikit yang mempunyai pemahaman yang mendalam tentang proses dan tata cara pengambilan specimen darah vena. Penilaian pengambilan specimen darah dengan kategori tidak lulus dapat disebabkan karena adanya factor internal maupun eksternal dari mahasiswa. factor internal diantaranya adalah minat, bakat, motivasi, tingkat intelegensi, sedangkan factor eksternalnya diantaranya adalah factor metode pembelajaran dan kurikulum. Prestasi belajar individu dipengaruhi oleh banyak factor baik yang berasal dari diri siswa ( factor internal) maupun dari luar mahasiswa ( factor eksternal).

Tetapi setelah dilakukan test simuasi pengetahuan dengan kategori tidak lulus menjadi $0(0.0 \%)$ dari 12 $(75,00 \%)$. Secara teori disebutkan bahwa semakin banyak seseorang mendapatkan informasi mengenai suatu pembelajaran maka pengetahuannya pun akan meningkat. Akan tetapi bila sumber informasi tidak tepat, maka tidak menjamin terbentuknya pengetahuan yang baik.(Notoatmodjo, 2010).

Tujuan metode simulasi yaitu membantu peserta didik mempraktikan keterampilan dalam membuat keputusan dan penyelesaian masalah, mengembangkan kemampuan interaksi antarmanusia dan memberikan kesempatan peserta didik untuk menerapkan berbagai prinsip, teori, serta untuk meningkatkan kemampuan kognitif, afektif, dan psikomotor.

Kelebihan metode simulasi, Memperkaya pengetahuan, sikap dan keterampilan, serta pengalaman yang tidak langsung diperlukan dalam menghadapi berbagai masalah sosial., Peserta didik berkesempatan untuk menyalurkan perasaan yang 
terpendam sehingga mendapat kepuasan, kesegaran, dan kesehatan jiwa., Sekalipun bukan tujuan model ini, melalui simulasi dapat dikembangkan bakat dan kemampuan yang mungkin dimiliki oleh peserta didik, misalnya dalam seni drama, bermain peran, dan sebagainya.

Kekurangan metode

Simulasi, Pengalaman yang diperoleh melalui simulasi tidak selalu tepat dan sempurna dengan kenyataan dilapangan atau dalam kehidupan.Tidak jarang simulasi dijadikan sebagai alat hiburan, sedangkan fungsinya sebagai alat belajar jadi terabaikan.Pelaksanaan simulasi sering menjadi kaku, bahkan jadi salah arah, karena kurangnya pengalaman keterampilan atau penguasaan siswa terhadap masalah sosial yang diperankan.Simulasi dipengaruhi oleh faktor-faktor emosional seperti rasa malu, ragu-ragu, atau takut yang dapat memengaruhi peserta didik dalam melakukan simulasi.Simulasi menuntut hubungan informal antara guru dan peserta didik yang akrab dan fleksibel serta ruang dan fasilitas yang selalu tersedia dengan baik.

Menilai penilaian pengambilan specimen darah pada mahasiswa untuk mengetahui teknik pengambilan darah vena yang baik dan memenuhi syarat untuk dilakukan pemeriksaan.
Pengaruh Metode Pembelajaran Praktikum SimulasiTerhadap Pencapaian Kompetensi Klinik Mahasiswa

Hasil analisa tentang Pengaruh Metode Pembelajaran Praktikum SimulasiTerhadap Pencapaian Kompetensi Klinik Mahasiswa diatas dengan menggunakan uji $t$ berpasangan didapat nilai signifikan $0,000<\alpha=0,05$ maka Ho ditolak yang berarti ada pengaruh sebelum dan sesudah pemberian metode pembelajaran praktikum simulasi.

Simulasi adalah metode pembelajaran yang menyajikan pelajaran dengan menggunakan situasi atau proses nyata, dengan peserta didik terlibat aktif dalam berinteraksi dengan situasi di lingkuangannya (Nursalam, 2007).

Pada penelitian yang dilakukan Andriani (2006), meneliti tentang pengaruh metode demonstrasi cara perawatan payudara terhadap kelancaran pengeluaran ASI pada ibu post partum di Ruang Perawatan Nifas RSIA Sitti Khadijah I Muhammadiyah Cabang Makassar menunjukkan dari hasil penelitian didapatkan bahwa pada kelompok ibu post partum yang diberikan penjelasan dan demonstrasi (Kel A : $\mathrm{P}+\mathrm{D})$ ada 60,0\% yang melakukan perawatan payudara dengan kategori baik dan 40,0\% yang melakukan perawatan payudara dengan kategori kurang. Pada kelompok ibu post 
partum yang hanya diberikan penjelasan tanpa demonstrasi (Kel B : P) ada 40,0\% yang melakukan perawatan payudara dengan kategori baik dan 60,0\% yang melakukan perawatan payudara dengan kategori kurang. Sedangkan pada kelompok ibu post partum yang tidak diberikan penjelasan maupun metode demonstrasi (Kel C : tanpa P $+\mathrm{D})$ $0,0 \%$ ibu post partum yang melakukan perawatan payudara dengan kategori baik dan 100,0\% ibu post post partum yang melakukan perawatan payudara kategori kurang.

Pembelajaran praktek klinik dengan metode simulasi sangat berpengaruh dalam meningkatkan kemampuan psikomotor pada mahasiswa, suatu tingkatan dalam melakukan berbagai keterampilan (intelektual dan teknikal) yang berhubungan dengan prinsip prinsip dan teori dapat dicapai melalui pembelajaran praktikum. Untuk mempelajari keterampilan memerlukan petunjuk dari pengajar yang menciptakan pengalaman praktek agar peserta didik tahu apa yang harus mereka alkukan tindakan, dan dengan melakukan latihan latihan simulasi mahasiswa mampu mengintegrasikan dan menerapkan konsep - konsep, prinsip - prinsip dan teori ilmu pengetahuan dalam praktek klinik.

Evaluasi klinik pada dasarnya adalah kegiatan evaluasi hasil pendidikan yang dilaksanakan di klinik atau di tempat pengalaman belajar klinik mahasiswa. Evaluasi adalah proses stimulasi untuk menentukan keberhasilan. Evaluasi hasil pendidikan adalah proses sistematis untuk mencapai tingkat pencapain tujuan pendidikan yang terdiri dari kegiatan mengukur dan menilai.

Mengukur adalah kegiatan mengamati penampilan peserta didik berdasarkan indikator yang telah ditetapkan dan menggunakan alat dan metode pengukuran tertentu. Menilai adalah membandingkan hasil pengukuran penampilan peserta didik dengan kriteria keberhasilan yang ditetapkan. (Nursalam Ferry Efendi 2008)

Belajar adalah suatu proses perubahan tingkah laku atau kecakapan manusia berkat adanya interaksi antara individu dengan individu dan individu dengan lingkungannya sehingga mereka lebih mampu beriteraksi dengan lingkungannya. Dari pengertian tersebut dapat disimpulkan bahwa seseorang yang telah mengalami proses belajar akan mengalami perubahan tingkah laku baik dalam aspek pengetahuan (kognitif), sikap (afektif), dan keterampilan (psikomotor). Teori belajar pada umumnya dibagi menjadi 4 golongan, yaitu teori belajar Behaviorisme, teori belajar Kognitivisme, teori belajar Humanistik dan teori belajar Sibernetik. Aliran tingkah laku menekankan pada hasil dari proses 
belajar. Aliran kognitif menekankan pada proses belajar. Aliran humanis menekankan pada isi atau apa yang dipelajari. Dan aliran sibernetik menekankan pada sistem informasi yang dipelajari.

Secara fundamental Dollar and Miller dalam Abin Syamsuddin (2007) menegaskan bahwa keefektifan perilaku belajar itu dipengaruhi oleh empat hal yaitu (1) adanya motivasi (drives), (2) adanya perhatian dan mengetahui sasaran (cue), (3) adanya usaha (response), dan (4) adanya evaluasi dan pemantapan hasil (reinforcement). Dalam penelitian menunjukkan metode simulasi dapat meningkatkan perhatian karena mahasiswa mengatakan merasa senang dengan

\section{PENUTUP}

\section{Kesimpulan}

Data yang diperoleh dari hasil penelitian mengenai pengaruh metode pembelajaran praktikum simulasiterhadap pencapaian kompetensi klinik mahasiswa adalah sebagai berikut :

$$
\begin{aligned}
& \text { Pre-test praktikum } \\
& \text { simulasi penilaian sikap, } \\
& \text { sebanyak } 9 \text { responden atau } \\
& (56,25 \%) \text { dan yang tidak } \\
& \text { lulus test penilaian sikap } \\
& \text { sebanyak } 9 \text { responden atau } \\
& (56,25 \%) \text {. } \\
& \text { Post-tes praktikum } \\
& \text { simulasi penilaian sikap, } \\
& \text { sebanyak } 16 \text { responden atau }
\end{aligned}
$$

praktek simulasi, sehingga ketertarikan tersebut mampu mempengaruhi hasil evaluasi pembelajaran praktikum kompetensi mahasiswa. Dari data yang didapat dalam penelitian dan ditunjang dari hasil penelitian yang relevan serta teori yang menunjang maka dapat disimpulkan bahwa pengaruh metode pembelajaran praktikum simulasiterhadap pencapaian kompetensi klinik mahasiswa dapat meningkatkan kompetensi praktikum mahasiswa, sehingga dalam melakukan proses pembelajaran sebaiknya kita harus mampu memilih metode dan media pembelajaran yang sesuai, dengan demikian tujuan pembelajaran yang kita harapkan dapat tercapai.

$(100,0 \%)$ dan yang tidak lulus test penilaian sikap sebanyak 0 responden atau $(0,0 \%)$.

$$
\text { Pre - test praktikum }
$$
simulasi penilaian pengambilan spesimen darah, sebanyak 4 responden atau (25.00\%) dan yang tidak lulus test penilaian sikap sebanyak 12 responden atau (75,00\%).

Post - test praktikum
simulasi
pengambilan spesimen darah,
sebanyak 16 responden atau
$(100,0 \%)$ dan yang tidak
lulus test penilaian
pengambilan specimen darah


sebanyak 0 responden atau $(0,0 \%)$.

Pengaruh metode pembelajaran praktikum simulasiterhadap pencapaian kompetensi klinik mahasiswa Penelitian ini menunjukan bahwa adanya pengaruh metode pembelajaran praktikum simulasiterhadap pencapaian kompetensi klinik mahasiswa dengan tingkat signifikan $p=$ 0,000 .

\section{Saran}

Berdasarkan hasil penelitian dan analisa data mengenai pengaruh metode pembelajaran praktikum simulasiterhadap pencapaian kompetensi klinik mahasiswa maka penulis menyarankan :

\section{DAFTAR PUSTAKA}

Aprilia. (2013). Teori, A Landasan, 13-52.

Biges, S. (2018). Pedoman Penelitian Penyusunan, Penulisan, Ujian, dan Penilaian Skripsi.

Wijayaningsih, K.S. (2014). Psikologi Keperawatan. Jakareta: CV.Trans Info Media

Bobaya J, Killing MA, L. J. \& L. N. (2015).
Bagi pendidik dalam menerapkan metode semulasi pendidik sebaiknya harus hafal betul tahapan simulasi sehingga apa yang diterima mahasiswa benar sesuai teori yang ada.

Bagi institusi

pendidikan untuk selalu memperbarui media pembelajaran, karena peningkatan teknologi mempengaruhi

penggunaan media dalam pembelajaran.

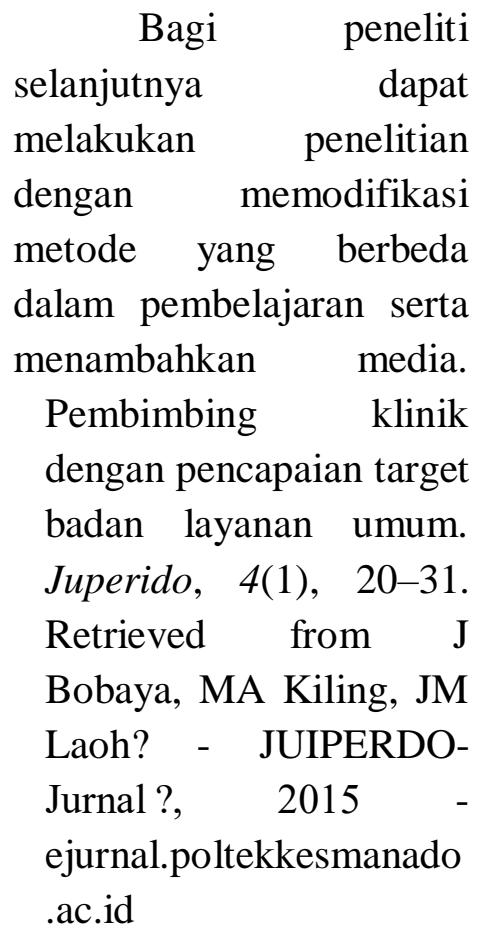

Chien, E. Y. T., Liu, W., Zhao, Q., Katritch, V., Won Han, G., Hanson, M. A., ... Stevens, R. C. (2010). Structure of the Human Dopamine D3 
Receptor in Complex with a D2/D3 Selective Antagonist. Science, 330(6007), 1091-1095. https://doi.org/10.1126/s cience. 1197410

Machfoedz, I. (2017). Metodologi Penelitian Kuantitatif dan Kualitatif Bidang Kesehatan, Keperawatan,

Kebidanan, Kedokteran. Yogyakarta: Fitramaya.

Pamungkas, R. A. (2017). Metodologi Riset Keperawatan. Jakarta: Trans Info Media.

Safaria. (2007). B A B Pustaka, Kajian, 12-36.

Saryono. (2011). Metodologi Penelitian Kesehatan. (A. Setiawan, Ed.). Yogyakarta: Mitra Cendekia Press.

Machfoedz, I. (2017). Metodologi Penelitian Kuantitatif dan Kualitatif Bidang Kesehatan, Keperawatan, Kebidanan, Kedokteran. Yogyakarta: Fitramaya.

Tursina, A., Safaria, T., \& Mujidin, M. (2016). Pengaruh Bimbingan Preceptorship Model Kognitif Sosial Terhadap
Peningkatan Kompetensi Klinik pada Mahasiswa. Jurnal Bimbingan Dan Konseling, 5(1), 79-87. https://doi.org/10.12928/ psikopedagogia.v5i1.459 3

Nursalam, Ferry Efendi. (2012). Pendidikan Dalam Keperawatan. Jakarta: Salemba Medika Siti Aisyah (2010). Penerapan Media Audio Visual dan Demostrasi Sebagai Upaya Meningkatkan

Kompetensi Rawat Luka Pada Praktikum Kebutuhan Dasar Manusia.http://eprints.un s.ac.id/2394/1/16763030 9201002061.pdf

Riska Aprilia Wardani (2011). Pengaruh Metode Demostrasi Terhadap Prestasi Belajar Mata Kuliah Askeb II Persalinan ( Standart Asuhan Persalinan Normal ) Ditinjau Dari Motivasi Belajar Pada Mahasiswa Prodi Kebidanan Stikes Dian Husada Mojokerto.http://eprints. uns.ac.id/8128/1/219671 711201105071.pdf.

Giyanto 
(2010).Pengaruh Metode

Pembelajaran dan

Motivasi Belajar

Terhadap Kompetensi

Komunikasi Terapetik.

Sri Ernawati (2008).
Pengaruh
Penggunaan
metode konseptual
dalam bimbingan
praktek
keperawatan
terhadap

pencapaian

kompetensi.

https://eprints.uns.a

c.id/4219/1/714906

07200905121.pdf

Maria Anita Yusiana \&

Nyoman Anita

Damayanti. (2011).

EvaluasiPenerapan

PembelajaranKlini

kKeperawatanMeto

deBedside

Teaching 